\title{
The Theory of Interpretation in Solving Contemporary Legal Issues: With A Focus on the Instrument of ljtihad
}

\author{
Abdulrahman M.A.Albelahi ${ }^{1, *}$, A. Ali $^{1}$, Faten Mohmed $^{1}$, and Metwally $\mathrm{Ali}^{1}$ \\ ${ }^{1}$ School of Human Development and Technocomunication, Universiti Malaysia Perlis, Perlis, Malaysia
}

\begin{abstract}
Since the beginning, legal theory has concerned itself with the establishment of principles and precepts that govern the procedure of legal interpretation, from the initial stages of the judicial reasoning down to the promulgation of ruling and their implementation, Islam is a total way of life. Muslims are obliged to abide by the rules of Allah in every aspect of their lives, always and wherever they live. However, the actual rules of Allah as given in the Qur'an and the sunna are limited. The Qur'an contains only six hundred verses directly related to laws, and there are approximately two thousand hadiths. The function of interpretation is to discover the intention of the Lawmaker of the matter, therefore, interpretat primarily concerned with the discovery of that which is rot self-evident the objective of interpretation is to ascertain the intention $\mathrm{c}$ the Lawmaker with regard to what has been left unexpressed as a matter of necessary interference from the surrounding circumstances. Sometimes, the textual sources did not provide detailed guidelines in which to derive the law, and then the role of interpretation is important to determine the law. In Islamic law the role of Ijtihad undoubtedly important in order to meet new problems. But some of the Jurist contended that the role of Ijtihad had ended and we have to follow the rule that has been stated. An explanation given to this trend is that a point had been reached at which all essential question of law had been thoroughly discussed and further deliberation was deemed unnecessary. In Common law, man-made law and legislation are related to one another within a philosophy of law. Parliament makes law and it is the duty of the courts to give effect to them if properly enacted. While courts may rule that a particular statute or section is invalid for various reasons such as unconstitutionality, they cannot say, "We shall change this Act because it is not appropriate". That function belongs to Parliament (Wu Min Aun 1990: 120). So as in Islamic law, the Lawmaker is Allah S.w.t and the sacred text (Quran) is legislated due to His intention whereas Sunnah of the Prophet Muhammad is enacted due to the Prophet's intention. Therefore, Ulama of Usul Fiqh, in making any Ijtihad, they are du y bound to be guided by Quran and Sunnah.
\end{abstract}

\section{Background Search}

Islam, the fastest growing religion in the world, with over 1.2 billion followers, has the astounding capability of adapting to ever changing conditions. Recent international events have intensified interest among religious leaders, scholars and educational professionals about the way Shariah (Islamic law) is taught $\&$ adopted in Muslim society. The Quran has given the fundamental education and knowledge but the Muslim scholars must interpret this fundamental knowledge wisely in accordance with the spirit of the time in which we live .Shariah (Islamic law) is subject to interpretation in order to meet the ever-changing needs of society. Its guiding principles were designed to protect the individual and the society so that it was not established as a set of fixed rules. To respond to the changing needs of Muslim societies, muslim jurists and scholars have relied on the well-established process of change, ijtihad. This process is based not only on the holy book (Qur'an) and religious tradition (Sunna), but also on reason, deduction, and prioritization. Ijtihad is practiced by the jurisprudent to discover secondary divine legislation (laws). Ijtihad is defined in different ways.

The terms 'mujtahid' and 'ijtihad' are nowadays among those which have acquired great currency, even sanctity, among the Shi'ah. One would be surprised to know that the term ijtihad was formerly, from the times of the Prophet (S) and for several successive centuries, a Sunni term. It became Shia after undergoing a change of meaning, or what would be more precise to say, the term remained specifically Sunni for several centuries and became 'Muslim', in the wider sense, that is, after undergoing a change of meaning and dissociating itself from its earlier particular sense.

'Ijtihad' in the Sunni Tradition Sunni scholars narrate a hadith that the Prophet (S), while sending Mu'adh to Yemen, asked him as to on what he would base his judgment. "In accordance with the Book of Allah", replied Mu'adh, "But what if you don't find it there?" inquired the Prophet (S). "According to the Sunnah of the Apostle of Allah", replied Mu'adh. "But what if you don't find it there too?" asked the Prophet (S) again. 'I will exert my own opinion', replied Mu'adh. The

\footnotetext{
* Corresponding author: bkaifi@hotmail.com
} 
Prophet (S) put his hand on Mu'adh's chest and said: "Thank God for assisting His Apostle with what he loves." They have narrated other traditions on the subject to the effect that either the Prophet (S) directly commanded his Companions to exercise ijtihad in case they could not

Find a rule in the Book and the Sunnah, or to the effect that he approved of the practice of his Companions that practiced ijtihad. To the Sunnis, this is something definite, confirmed by consensus (ijma'). About the Holy Prophet (S) himself, they have said that some of his injunctions were purely based on personal ijtihad not on revelation. Even in their works on jurisprudence ('ilm al-'usul) the problem is raised whether or not the Prophet (S) could make errors in his personal ijtihad. They have narrated traditions in this regard and transmitted reports of the Companions as to how they justified their own actions or those of others on the basis of ijtihad. We abstain from quoting any of them here for the sake of brevity.

\subsection{Definition of ljtihad}

Ijtihad is defined literally as striving, exerting, selfendeavor or making an effort to deduce a principle and exerting oneself to the utmost. While legally it refers to the striving of the jurists to the point of mental exhaustion to derive principles and rules of law from evidence found in the sacred texts of sources (Codd 1999: 115

Mashood A. Baderin - 2017 - the Islamic legal Theory, volume 1.)

However, it has also been described as a rethinking (Fatawa Qadi Han, (I-VI), Eqypt: Bulaq RAHMAN, Fazlur (1962). "Post-Formative Developments in IsIam" in: Islamic Studies, Karachi, 1, 4 RIDA, M. Rashid $(1324 A H))$ or most commonly, as independent reasoning.

It is an activity, a struggle and a process to discover the law from the texts and to apply it to the facts awaiting decisions. The jurist stay as close to the meaning of the texts as is possible. The purpose is to discover the true intent of the Lawmaker.

In jurisprudential sense, the meaning of Ijtihad is exercising of one's opinion or judgment. It means that in a case where the Divine dicta is absent or implicit, one should see what would be more acceptable to one's intelligence and taste, or nearer to truth and justice, or analogous to other Islamic laws and to adopt it for his judgment (Mutahhari 2002: 2).

\subsection{Basic of ijtihad}

Ijtihad is the most important source of Islamic law next to the Quran and Sunnah. The main difference between ijtihad and the revealed sources of the shariah lies in the fact that ijtihad is a continuous process of development whereas divine revelation and Prophetic legislation have discontinued with the demise of the Prophet.
The role of ijtihad had been recognized in the Quran and Sunnah for example in

Surah AI-Ankabut 69 ; And those who strive for Us We will surely guide them to Our ways. And indeed, Allah is with the doers of good.

Which means, "And those whose strive in Our (cause) We will certainly guide them to Our Paths. For verily God is with those who do right". This ayat clearly allowed the foundation of the principle of Ijtihad to meet the growing of legal ruling in the future. It is because Quran only provides basic principles and few details legal provisions, but mostly it needs elucidation and elaboration of those matters. This process of inference is intended to meet the diverse needs of ever growing life in the developing society in the future. By this inference and logical deduction, then all future problem of human society could be solved by evolving guiding rules

Another surah which encourages to search a knowledge so as to arrive at sounh, decisions, can be seen in Surah An-Nisa' 83: And when there comes to them information about [public] security or fear, they spread it around. But if they had referred it back to the Messenger or to those of authority among them, then the ones who [can] draw correct conclusions from it would have known about it. And if not for the favor of Allah upon you and His mercy, you would have followed Satan, except for a few.

Which means, "And when there comes to them tidings of safety or fear, they spread all around, whereas if they had referred it to the Prophet and to such other persons as are in authority those among them who can search out of knowledge of it, would have known it".

The term used in this verse is 'to such other persons as are in authority' or ulul amri in Arabic means that men who are in authority, or who are in a position to search out the knowledge. The Quran, while thus encouraging the process of ijtihad, indicates that the function should be carried out by the Prophet and by ulul amr or men in authority, power, wisdom and understanding.

The famous and well-known hadith, where Muaz bin Jabal has been appointed as the Governor of Yemen; The Prophet asked him:

"0 Muaz, by what rule would you be guided?" He replied, "By the Law of the Quran". "But if you find no direction therein?" asked the Prophet. "Then I will act according to the Sunnah of the Prophet", replied Muaz "But what if that also does not help?" he was again asked. "Then I will exercise my judgment and act accordingly" He replied it. The Prophet raised his hands in

satisfaction and thankfulness to God and uttered, 'Praise be to Allah, who guides the Messenger of His Apostle as He pleases".

This hadis shows the approval of the principle of ijtihad by the Prophet. This is involving the exercise of one's own judgment when there are no specific directions in the Quran or the Sunnah. It further shows that during the Prophet time, the companions were aware of the 
principle of ijtihad and it was freely resorted to when necessary in order to meet new circumstances. Subsequently, companions followed the principle of ijtihad in order to meet the changes of time and society and it was proved to be successful.

\section{Procedure of ljtihad}

Since ijtihad occurs in a various forms such as Quran, Sunnah, qiyas, istihsan, maslahah, custom (urf), etc, each of this is regulated by its own rules. There is, in other words, no uniform procedure for ijtihad as such.

From the viewpoint of the procedure that it employs, ijtihad may occur in any of the following four varieties. First in the form of a juridical analogy, this is found on an effective course. The second variety of ijtihad consists of a probability without the presence of any effective course, such as practicing ijtihad in regards to ascertaining the time of solat or the direction of qiblah. The third type of ijtihad consists of the interpretation of the source materials and the deduction of ahkam from existing evidence. This type of ijtihad is called explanatory ijtihad which takes priority over the analogical ijtihad. The last type of ijtihad referred to as ijtihad istislahi which is based on maslahah and seeks to deduce the ahkam in pursuance of the shariah, which may take the form of istislah, juristic preference, the obstruction of means, etc. Imam Shafii however, accepts only the first type, namely analogical ijtihad but to the majority of ulama, ijtihad is not confined to analogical deduction and may take the form of any of the foregoing varieties (Kassab 1984: 24 THE CONCEPT OF IJTIHAD IN THE HISTORY OF ISLAMIC JURISPRUDENCE)

As far as sources of law are concerned, Ouran ranks in priority and followed by the Sunnah. When the matters are silence both under the revealed sources of law then the rule of interpretation plays an important role. Accordingly, ijtihad is also accounted as one of the sources of Islamic legislation, like the Ouran and Sunnah, although not as a source parallel to these two. As long as a rule is to be found in the Ouran and the Sunnah, the need for ijtihad does not arise.

\section{The Need and Justification of ljtihad in Modern Times}

The role of ijtihad cannot be denied due to changes in the society and circumstances. A new role has to be formulated in order to meet a modern era in which the need and justification of ijtihad in the modern times is very important.

Mohd Abduh had advocated the need for fresh reinterpretation of the principles found in the divine revelation as the basis of the legal reforms. He also argued the ijtihad was not only the right of modern day jurists but the only way to which Islam could adapt itself to the needs of today's society (Glassse, The Concise Encyclopaedia of Islam, 1999: 121).
The role of ijtihad can be seen during the time of Caliph Umar and Ali practiced the ijtihad even in the presence of a clear Ouranic and Sunnah injunctions. So, in the modern times, ijtihad is used in a largely peripheral manner and cannot be used in any other way unless there is a complete overhaul of the legal system. Therefore, to be reused properly within a new Islamic framework to effect modern legal reform, then ijtihad will have to be modified.

In order to implement ijtihad in the modern time, then it must be freed from the limitation imposed on it previously ("Al-Ghazali employed dialectical methods in presenting his theology and also claimed for himself the right of independent Ijtihad which had been curtailed by the orthodoxy" (Gatje, The Qur'an and its exegesis, 1999: 129). The example of the limitation is that the requirement of the mujtahid itself, which is quite impossible, and hardly be found especially in the modern times.

\section{Qualifications of Mujtahid}

Interpretation will be reliable only of those who engage themselves in inquiry and investigation, having deep knowledge and insight in legal matters supported by technical expertise in determining the meaning, import and applicability of a particular injunction. The interpreters must have an ability to understand worldly affairs as well as public policy. This can be referred to Surah Aanbyaa Ayat 78-79. We bestowed the same favour upon David and Solomon. Recall, when they gave judgement regarding a tillage into which the sheep of some people had strayed at night, and We were witnesses to their judgement. We guided Solomon to the right verdict, and We had granted each of them ${ }^{70}$ judgement and knowledge. We made the mountains and the birds celebrate the praise of Allah ${ }^{71}$ with David. It was We Who did all this. So, it is clear from the above statement that not everybody is qualified to form a valid ijtihad but only certain people who had fulfilled all the requirements to be a mujtahid. Weiss in his article said that "if every man was a mujtahid, there would be no law in the ordinary sense; every man would be law unto himself. The implications, which this would have for society, can hardly be comprehended. Therefore, it is in interest of social stability that not all choose to acquire the qualifications which are prerequisites of ijtihad" (AI-Amini IJTIHAD Interpreting Islamic Principles1986: 207).The mujtahid should have knowledge of the Quran and Hadith, he should be able to distinguish the nasikh from the mansukh, the amm from the khass, the mujmal from the mubayyan and the muhkam from the mutashabih. He should be familiar with the Quranic vocabulary and terminology, know the circumstances in which a particular verse was revealed and have knowledge of the successive generations of narrators and transmitters of hadith. He should also be able to reconcile the apparently conflicting traditions. In addition to all that, he should practice ijtihad and exercise his personal judgment in particular case. 
It seems at these qualifications in certain aspects are very good, where they are very experts in Islamic jurisprudence and Islamic laws and they can answer all the questions raised to them. But on the other hand, these qualifications hardly to be achieve at the present times. But, indeed, they should be able to know all the related fields of the Quran and Sunnah.

According to al-Shawkaniyy, one who attempted to conduct ijtihad had to acquire a certain degree of knowledge and other requirements:

$\checkmark$ Who master all requirements for general ijtihad.

$\checkmark$ Who are self-sufficient to understand the sources.

Who know the reference of the shariah.

Who specialized in a certain branch of non-religious sciences yet attempting to understand the shariah. .

Few the actual conditions, some ulama has aptly observed that. Qualifications required of a mujtahid would seem to be extremely moderate and I there can be no warrant for supposing that men of the present day are unfitled to.

He had made relatively easy and possible the requirement for mujtahid since he is the most radical among his contemporary informers towards the reopen "the closing of the door of ijtihad". Some Maliki, Hanbali and Zahiri ulama also held the view that when a person is learned in a particular area of the shariah he may practice ijtihad in that area only. This would be no way violating any of the accepted principles of ijtihad (Badran Can Faith-Based NGOs Advance Interfaith Reconciliation? 1984: 486).

Some observers have suggested that the practice of ijtihad WCls abandoned partly because the qualifications required for its practice $\mathrm{w}$ re made so immaculate and rigorous and were set so high that they were humanly impossible of fulfillment (Kassab 1984: 38 Previous source). This is however a implausible supposition which has been advanced mainly by the proponents of taqlid with a view to discourage the practice of ijtihad. Acquire such qualifications

\section{Instruments of ljtihad}

\subsection{In the Form of Juridical Analogy (Qiyas)}

If new cases occurred which were not provided in the Quran, the Sunnah or the consensus of opinion, the jurists found them compelled, in seeking solutions to have recourse to reason, logic and opinion for example, applying Qiyas. However, they were not entirely free or unrestrained for they had to adhere to scientific rules and premise which they classified in a new category known as analogy. The jurists derived this new source from the fundamental judicial premise that all rules are based upon objectives and interest and those objectives and interests are the causes for the rules. Hence from the rules they deduced their causes. Having done so in reference to any particular problem, they were able to apply the same rule to another problem whenever the cause for both was identical (Ziadeh, A Study of a Revivalist Movement in Islam 1987:79).

A case in point is the prohibition of seeking marriage with a woman already engaged to another person. The prohibition is derived from the hadith of Prophet; "Do not ask for a woman in marriage when another Muslim has already done so". The ratio decided of this prohibition lies in the fact that this would violate the brotherhood and unity among fellow Muslims. This rule can simply be applied to other similar contract such as sale of property, hire purchase, rent, etc.

In The Form of Interpretation of the Source Materials al Quran

The Quran is the first and important sources of Islamic law. If the Quran proves something, it is considered binding. The related Quranic verse (And We sent not before you except men to whom We revealed [Our message]. So ask the people of the message if you do not know. AI-Nahl: 43) provides the authority to pursue ijtihad and contemplated of the existence of learned man at all times. As far as Quran is concerned, its authenticity is unquestioned. What is expressed in the Quran is the expression of the absolute authority of God. But it is fairly clear that the Quran, which is essentially a religiomoral scripture, does not provide comprehensive provision for the formation and the development of the shariah. The Quran only supplied elementary rules for few cases (Hidayatullah The Origins of Islamic Law Constitutional Rights Foundation 1975: 75).

So we may say that Quran only provides general principles and only a few of normative verses, which, of course, need to be interpreted especially for the changes of the society of the modern times. In other words, it must be interpreted in the light of modern ages. Therefore the Quran contains a significant number of verses with legal bearing. It is these verses, which provide Muslims raw material out of which legal elaboration, were made and around which their legal speculation remained focused. For example, the Quranic verse, which needs further elaboration as follows: "Prohibited to you (for marriage) your mothers, daughters". Prohibited to you [for marriage] are your mothers, your daughters, your sisters, your father's sisters, your mother's sisters, your brother's daughters, your sister's daughters, your [milk] mothers who nursed you, your sisters through nursing, your wives' mothers, and your step-daughters under your guardianship [born] of your wives unto whom you have gone in. But if you have not gone in unto them, there is no sin upon you. And [also prohibited are] the wives of your sons who are from your [own] loins, and that you take [in marriage] two sisters simultaneously, except for what has already occurred. Indeed, Allah is ever Forgiving and Merciful.AI-Nisa': 23. It is unanimously agreed that marriage with one's mother and daughter is prohibited. However, the word "daughter" could be taken for its literal meaning which would be a female child born to a person either through marriage or zina. Judicially, the word daughter can only mean a legitimate daughter. Jurists had exercised ijtihad to come to the own conclusion. For example, Hanafi stated that this prohibition applies to both legitimate and illegitimate daughters, whereas Shafii opined that this prohibition only applies to legitimate daughters. Even the child born out of wedlock, but the father of the child stills the same 
man and considers the father of the child then he cannot be permitted to marry his own child.

\subsubsection{Sunnah}

Traditional theory is that Sunnah confirms the Quran, assists in its interpretation or fill in the lacunae. The Sunnah is the second most important source of Islamic law. Besides getting proof of continuous ijtihad in hadith, the Sunnah itself

According to AI-Faruqi needs ijtihad. For example, where the rulings of Sunnah were changed in order to reflects the changes of circumstances. The Prophet had granted the right to attend the mosque for congregational prayer. Due to change of circumstances, however, Aishah later changed this ruling as she concluded "had the Messenger of God observed what was happening to woman, he would have forbidden them from attending the mosque" (AI-Ghazaliyy: 48).

\subsection{In the form of a probability without the presence of any effective course}

\subsubsection{Custom}

Custom is defined by some jurists as recurring practices, which are acceptable to the people of sound nature. Thus, the legal theory of Islam, on the whole, does not recognize custom as an independent or formal source of law. But the ulama accepted the authority of general usage, satisfying the juristic standards, for the purposes of interpretation and application of legal rules dealing with worldly affairs. They admitted a limited contribution of custom in the growth of law. The mainspring of this growth was however, the interpreter (mujtahid) (Santillana 1931: 307).

No custom; whatever is the degree of its utility therefore, became law $i$ any judicial sense unless it was authoritatively recognized. In order to constitute a valid basis for legal decisions, customs must be sound, and reasonable. It has been accepted as a binding authority and been accepted in order to solve contemporary problems. In Malaysia, the most popstar. Custom, which has been recognized and enacted by Islamic law via the ins Rent of ijtihad, is jointly acquired property. It was defined as property acquire during the subsistence of a marriage by a husband and wife out of their joint res6urces or by their joint effort (Mat 1985: 92). A claim over the jointly acquired property often arises from divorce or from the death of either husband or wife. It is clear cut evident that there is no specific provision under Islamic law concerning the said property and yet, the claim of jointly acquired property has been practiced in courts and judicial decisions on the claim are mainly based on custom.

It is to be noted that most of the states in Malaysia have special provisions concerning JAP. For instance, section 58 of the Selangor Islamic Family Law Enactment No. 4 of 1984 provides to order the division between the parties (husband and wife) of any assets acquired by them during the marriage by their joint efforts.

In the case of Hajah Lijah bt. Jamal V. Fatimah bt. Mat Diah, (1956) 16 MLJ 63, Briggs J, says that since there is a clear recognition on jointly acquired property in many states and courts, thus, any regulation concerning jointly acquired property is to be part of the personal law in the state. Tun Salleh Abbas in his judgment in the case of Boto' bt. Taha v. Jaafar bin Muhamed, (1985) 2 MLJ 98 also says that jointly acquired property is a custom practiced by the Malays Muslim. Thus, since custom has been recognized as a basis of law, ijtihad has been made in determining the validity of jointly acquired property under Islamic law in Malaysia.

\subsection{In the form deducting hokum in pursuance of the purpose of shariah}

\subsubsection{Maslahah}

According to AI-Ghazali, maslahah consists of consideration which secure a benefit and prevent a harm but harmonious with the objective of shariah, that is to protect five values; Religion, life, lineage, intellect and property. The usefulness of this principle of law in contemporary issues is beyond doubt since both Quran and Sunnah do not textually cover current issues.

The Islamic Religious Council of Johore, issued a fatwa, effective as of 13 November 2001, which requires mandatory HIV/AIDS blood test for prospective Muslim couples prior to registration of marriage. Reports indicate that the fatwa was under consideration over a period of months prior to its eventual approval and implementation. Upon announcing its proposed implementation, the Menteri Besar of Johor made a brief statement in which he said that the fatwa was taken in accordance with the principle of syara' in Islam, which safeguards religion, life, property, intellect and lineage. Fatwa can become the binding law if the Islamic Religious Council submits it to the legislative authority for ratification, either by

Parliament or the state legislature as may be the case (Karnali 2001: 116).

The shariah doctrine of maslahah entitles the political authority and those in charge of the community affairs, the ulul amr to rn, decisions, enact legislation and issue fatwa, which are designed to secure the public welfare. It is the Islamic duty of the government to promote and advance the maslahah of the people. maslahah as such is an important goal and hilosophy of Islamic government.

\subsubsection{Istihsan}

The jurist who resorts to istihsan may find the law to be either too general or too specific and inflexible. In both cases, istihsan may offer a means of avoiding hardship and solution, which is harmonious with the higher objectives of the shariah. For example, the ruling of 
Saydina Umar, where during famine he was not enforce a hadd penalty of the amputation of the hand for theft. Saydina Umar had departed from existing law in order to preserve public interest and justice.

Istihsan enable a choice between alternative solutions, it contemplates the relatives merit, and demerits of each of the alternatives. In this sense, istihsan offers considerable potential for innovation and for imaginative solutions to legal problems. The question is istihsan is not merely to find a solution to a particular problem but to find a better solution, which is already, exists.

Generally speaking, the scientific and medical advancement primarily aim at the preservation of some benefit in Islam especially in the area of biomedical technology. For example, the donation of human body organs in its contemporary state are not textually covered by Quran and Sunnah and is the new issue which the ancient jurists not dealt with. It is agreed among the jurists that the basic rule is the forbidding of the utilization and exploitation of the parts of the human body, either because of its dignity or value or because no legitimate use can be made of the parts. This prohibits the donations of human body organs. This is based on Surah An-Nisa' 29-30, Allah says:

O you who have believed, do not consume one another's wealth unjustly but only [in lawful] business by mutual consent. And do not kill yourselves [or one another]. Indeed, Allah is to you ever Merciful. And whoever does that in aggression and injustice - then We will drive him into a Fire. And that, for Allah, is [always] easy. Which means, "Nor kill (destroy) yourselves, for verily God had been to you most merciful".

\section{The Prophet also said :}

"The breaking of the dead's person bone is just like the breaking of his bone while alive".

On the other hand, as a result of the advancement in this medical issue, there is need for a new ruling. The recognition of the jurists right to exercise istihsan in donation of human bod organs as a result of scientific advancement requires departure from the principle by allowing the donation to prevail over such prohibition. Therefore, based on the right of the jurists to exercise istihsan, that is to choose the least of the two harms in order to reject the worst of the two, the donation of human organ is permitted.

\section{Fatwa Making Procedure in Malaysia}

Fatwa means a response given by a qualified person who expounds the ruling 9 shariah on a particular issue that is put to him by a person or a group of persons. Fatwa also can be defined as a formal legal opinion given by a Mufti in an answer to a question submitted to him either by a judge or private individual (Ishak 1981: 9).

Fatwa is often used synonymously with ijtihad, both of which involve intellectual effort of a qualified scholar to provide shariah-based responses to real issues.
Fatwa or ijtihad that is based on interpretation and personal opinion of the mufti is normally not binding on anyone unless and until it is published in the States's gazette. The important element in fatwa is that it always involves a question and an answer to a new case, but if a hukum is issued without any query, it is no called fatwa but a mere ijtihad.

In Malaysia, Fatwa Committee of every state is established under the respective States' Administration of Islamic Law enactments. The Committee shall consists of the Mufti, Deputy

Mufti, two members of the Majlis nominated by the Majlis, not less than two fit and proper persons to be appointed by the Majlis and an' officer of the Islamic Religious Department of the particular states to be appointed by the Majlis, who shall be the secretary.

Whenever the mufti proposes to make a fatwa he shall call for a meeting of the Committee for the purpose of discussing the proposed fatwa. Before the mufti makes fatwa, he may cause such studies or research to be conducted as he may direct and a working paper prepared.

In issuing any fatwa or certifying any opinion, the mufti shall ordinarily follow the accepted views of mazhab Shafii. However, if the mufti considers that following the view of the mazhab Shafii will lead to a situation, which is repugnant to public interest, the mufti may follow the accepted views of mazhab Hanafi, Maliki or Hanbali. For example, the use of local currency to replace the use of rice in zakat fitrah payment is in accordance with the opinion of mazhab Hanafi (Shuaib 2002 :273).

The mufti shall make and publish in the Gazette, a fatwa on any unsettled question relating to Isla ic law on the direction of the Yang di Pertuan Agong or maybe he do so on his own initiative or on the request made by letter addressed to a mufti. Upon publication in the Gazette, a fattwa shall be binding on every muslim residents in the particular state as dictate 0 this religion and it shall be the muslims' duty to up little unless he is permittee by Islamic law to depart from the fatwa because of personal observance, belief or opinion.

A fatwa shall also be recognized by all syariah courts im the particular states as authoritative of all matters laid down but not civil courts. However, once the civil courts call it, it should be observed and respected.

\section{Problem}

There are certain qualifications to be fulfilled before the person can be called as mujtahid. For example, he must possess $t$ e knowledge of the sources of the shariah, knowledge in Arabic. The problem faced at present is that despite the door of ijtihad having been declares widely open, but still we fail to detect any movement towards the regeneration of ijtihad. There are opinions also which stated that qualification of mujtahid is heavy and exacting. According to some scholar, this is another taqlid-oriented assertion by those who wished to bring ijtihad to be closed. 
Free development of the law was already existed. Rigidity was greatly increased by the development of the doctrine of the closing of the gate of independent reasoning. The jurists were restricted to the interpretation of the authoritative manuals of the schools, which generally were books written not by ancient masters of the schools but by the comparatively late scholars. In theory, therefore Islamic jurists since then have been mere imitators and copyists. In practice, of course, the development of the law has not stood still although it was, no doubt, slowed (Liebesny 1964: 18).

\section{Suggestion}

The contention made is not true since the qualifications were not excessive and were fulfilled frequently. Furthermore, the uncertainties surrounding ijtihad have in modern times been exacerbated by the spread of secularism and the fact that the state has become the sole law making authority in its own territorial domain. Assuming that mujtahid has been recognized, and then it should be possible to devise a procedure, which would integrate ijtihad in the legislation processes of Government.

Universities and legal professions in many Muslim countries are engaged in training lawyers and barristers in modern law streams, then these are their duties to institute an effective program of training for the prospective mujtahid. Abdul Wahab Khallaf suggests that the government in every Muslim country should specify certain conditions for attaining to the rank of mujtahid and this contingent upon obtaining a recognized certificate, which would enable the government to identify the mujtahid and to verify their views when the occasion so requires (Khallaf 1978 :49$50)$.

The view for collective ijtihad is mainly supported by Mohd Iqbal (1982: 174) in his work "Reconstruction of Religion Thought in Islam" that the power to carry out ijtihad and ijma' should be rested in the Muslim legislative assembly. There are suggestion also in support of the institutionalization of both ijma' and ijtihad within the fabric of modern government. Ijtihad in the past has been related to the juristic concept and remain preserving of the mujtahid. So ijtihad in the sense of self-exertion is a method of finding solutions to new issues in light of the guidance of wahyu. Scholars of shariah as well as experts in other disciplines must exercise so wider propositions and they must acquire mastery of the ruler data, especially in the Quran and Sunnah pertaining to his subject According to Coulson (Layish 1987: 225) there can be no doubt that the review of the existing commercial laws imported from the west in the light of the basis principles of the textual sources will eventually lead to a genuine Islamic law of contracts and commerce that will give shariah legitimacy to the principle of contractual freedom.

The enactment of modern codes and statutes is not enough, so this is the task of the court to adjust the new enactment to practical needs. If the courts, as has been the case occasionally, are too literal and strict in their interpretation and allow formalism to stifle and search for truth and the equitable application of legal rules, the law is likely to remain alien and often bewildering to the people at large .In order to serve rapidly changing social, economic and political conditions and new systems will, however also have to preserve flexibility.

\section{References}

1. AI-Ghazaliyy, Abu Hamid. Ihya Ulum ai-Din. 2nd Edition. Cairo: Darul Fikr. Khallaf. Abdul Wahhab, IImu Usul al-Fiqh (Kuwait: Darul Qalam, 1978)

2. F. Al-Attas, Islamic Perspective Journal 1(2), 7-16 (2009)

3. M. T. Amini, Fundamentals of Ijtihad (Delhi, 1986)

4. Badran, Abu AI-Ayrayn Badran, Usul al-Fiqh alIslami (Alexandria: Muassasah Shihab al-Jamiah, 1982)

5. Codd, A Critical Analysis of The Role of ljtihad in Legal Reforms in the Muslim World. Arab Law Quarterly, Kluwer Law International 14 (1999)

6. W. B. Hallaq, Journal of Studies Islamica 24 (63), 129-141, (1986)

7. C. Malik, God and Man in Contemporary Islamic Thought (Centennial Publishers, Beirut, 1972)

8. W. B. Hallaq, Journal of Middle East Studies 16(1), 3-41 (1984)

9. M. Hidayatullah, The Role of the Quran in the Development of the Shariah, Islam and the Modern Age (1975)

10. M. Iqbal, Reconstruction of Religious Thought in Islam (Ashraf Printing Press, Lahore, Pakistan, 1982)

11. M. Iqbal, The Reconstruction of Religious Thought in Islam (Lahore: Sh Muhammad Asyraf, 1982)

12. Ishak, Othman. 1981. Fatwa Dalam Perundangan Islam. Kuala Lumpur: Fajar Bakti Sdn. Bhd.

13. G. N. Jalbani, Teaching of ShahWaliyullah of Delhi (Ashraf Printing Press, Lahore, Pakistan, 1967)

14. H. Kamali, IIUM Law Journal 9(2), (2001)

15. A. A. L. Kassab, Adwa Hawl Qadiyyah AI-ljtihad Fi AIShariah AI-Islamiyyah (Cairo: Dar AI-Tawfiq, 1982)

16. A. Layish, Reforms In Islamic Commercial LawTowards A Reopening Of The Gate To ljtihad, Asean And African Studies 21 (1987)

17. B. Lewis, The Muslim Discovery of Europe (London Redwood Burn Ltd. Publishers, UK, 1982)

18. J. Herbert Liebesny, Stability and Challenge in Islamic Law (Middle East Institute, 1964)

19. M. K. Mas'ud, Iqbal's reconstruction of Ijtihad (Iqbal Academy Publishers, Lahore, Pakistan, 2003)

20. I. Mat, Adat and Islam in Malaysia: A Study On Legal Conflict and Resolution, Temple University Press. Santillana. 1931. Law and Society in the Legacy Of Islam (1985) 
21. M. M. Mutahhari, The Role of Ijtihad in Legislation. Translated from the Persian by Mahliqa Qara'1, 4(2), (2002)

22. F. Rahman, Post Formative Developments in Islam (Karachi: Islamic Studies, 1962)

23. A. Rahnema, Pioneers of Islamic Revival (Zed Books Ltd Publishers, London, UK edition, 1995)

24. B. Weiss, The American Journal of Comparative Law 26(2), 199-212 (1978)

25. B. Weiss, The American Journal Of Comparative La 26, (1978)

26. Wu Min Aun. The Malaysian Legal System (Longman Malaysia Sdn. Bhd., 1990)

27. R. Zia, R.:Transmission of Values in Muslim Countries: Religious Education and Moral Development in School Curricula. In CERC Studies in Comparative Education, Springer Netherlands 18(3), 119-134 (2007)

28. J. Ziadeh, The Philosophy of Jurisprudence. H IZBI (1987) 